\title{
Principles of Criminal Liability from the Semiotic Point of View
}

\section{Michał Peno ${ }^{1}\left[\right.$ (1) Olgierd Bogucki ${ }^{2}$}

Published online: 10 March 2020

(c) The Author(s) 2020

\begin{abstract}
Certainly principles of criminal liability may be understood as rules or norms outlining orders or prohibitions and standing out among other norms with their weight, for legal culture, legal doctrine, etc. In such a classic approach they are norms defining basic rights and obligations in the applicable criminal law (legalata level). However, is it the only possible and cognitively interesting meaning of the word "principle" in jurisprudence? From the semiotic point of view, they can occur in three forms: special-kind norms, teleological directives, rules which constitute valid performance of conventional activities (making criminal law). In an extra-directival sense these principles may be understood as models-descriptions of shaping the system of criminal law (or criminal liability as the core of criminal law). From a theoretical and practical point of view principles addressed to the legislator are extremely weighty-they can be called rules constructing the system of criminal liability. These all problems are discussed in the article.
\end{abstract}

Keywords Von Wright - Directives · Legal principle $\cdot$ Criminal law $\cdot$ Patterns of criminal law system $\cdot$ Rules for constructing legal system

\section{Introduction and Methods}

At first glance it might seem that the issues of principles of criminal liability are quite remote from the issues of semiotics. However, this study is to show that applying certain basic assumptions of broadly understood semiotics to the issues

Michał Peno

m.p.peno@gmail.com; michal.peno@usz.edu.pl

Olgierd Bogucki

olgierd.bogucki@usz.edu.pl

1 Institute of Legal Studies, University of Szczecin (Poland), Narutowicza 17a, 70-240 Szczecin, Poland

2 Institute of Legal Studies, University of Szczecin (Poland), Santocka 17c/7, 70-240 Szczecin, Poland 
of criminal liability gives interesting results. The semiotics perspective allows for a closer clarification of the status and content of the said "principles" as well as for distinguishing and characterizing closer the philosophical and political types of shaping criminal liability. In the first part of the paper certain basic semiotic notions and findings will be presented. It will provide a methodological framework for further parts of the study. Basing on these findings, an attempt will be made in further parts of the study to analyse the issue of criminal liability, and in particular of possible ways of understanding principles of criminal liability, rules of the structure of the system of criminal liability and types of criminal law [cf. 58, 59].

The chosen research problem affects the structure of the paper and the adopted research method. The paper's structure is built around individual substantive problems, which is why reporting fragments and fragments including authors' original findings could not be expressly separated from each other by placing them in separate points. These fragments intertwine. The basic research material involves cited source texts (the literature) and a critical analysis. An analysis of pertinent literatureis performed in the paper, though it is not only a juxtaposition of the most recent state of knowledge in the relevant scope. The quoted semiotic concepts are interpreted and applied to issues concerning criminal liability. On the one hand, such an application required specifying general terms of the semiotics of directives, on the other it allowed formulating and ordering certain specific issues associated with principles of criminal liability. In this sense it is then an original attempt to apply semiotic concepts to very specific problems of the theory of law and legal dogmatics. One can say that this paper is part of the mainstream of the analytical theory of law which involves application of logical and semiotic tools to an analysis of legal notions (which incidentally has a long tradition in Poland).

\section{Basic Conceptual Assumptions}

Without a doubt semiotics as a general study of signs may provide multiple perspectives for investigating legal notions. It is associated among others with the fact that within semiotics there is a multitude of problems, theories and traditions of thinking (e.g. on the one hand studies deriving from Pierce and on the other form Saussure; on the one hand studying the relationship of a designation and on the other investigating the pragmatics of a sign). From the point of view of this study it is essential that language expressions as signs may have different semiotic (pragmatic) functions. It is worth referring here to the pragmatic perspective of the theory of speech acts. According to one of the most common classifications in the theory of speech acts [66] the following types of utterances can be identified (their illocutionary force): assertives, directives, commissives, expressives, declarations.

As far as it is known, from the legal point of view directives (and its concepts) are the most essential. However, it is a very general category and from the legal point of view undoubtedly requires further specification (identification of subcategories). However, an attempt of such an identification is hindered by the fact that in legal studies there is a great diversity of using such expressions as "principle", "rule", "norm" or "directive". This is why some authors, in order to meet their theoretical 
objectives, assume certain regulatory definitions of these terms (see e.g. R. Alexy's understanding of a norm ${ }^{1}$ ). Taking the above into consideration, creating "the semiotics of criminal liability" is not possible without certain working terminological and notional assumptions as to the semiotic types of language expressions which will be significant from the point of view of this paper.

Firstly, as in G. H. von Wright [78; 79: 6-17], one needs to distinguish norms of conduct, (technical or teleological) directives and the so-called rules of meaning (or, more adequately - constitutive rules. The first have the nature of expressions that firmly order or prohibit something, the second ones point to measures sufficient to achieve a desired state of affairs, while the last ones address how to perform certain conventional acts (activities) in a valid way (for example validly establish a criminal statute-let us add that in order to make criminal law the philosophy of law requires that particular criteria are met).

Next, it needs to be noted that the term "principle" is very often used in legal science. This term has multiple meanings. In the theory of law we have a number of "theories of principles of law" which suggest assigning different content to this term. In turn, in practice the term "principle" is often used in a significantly different way. Not attempting here to analyse more closely the subject matter of principles of the law it needs to be noted at the same time that from the point of view of this paper two meanings of the term "principle" are essential. ${ }^{2}$ In the first one a principle is merely a norm of conduct (legal norm), significant from some point of view. Whereas in the second one a principle means a model (standard) of the shape of a legal institution (e.g. the principle of adversarial proceedings). The first meaning has evidently a normative (directival) character (a norm is a point of reference here). However, the second meaning is difficult to characterize. It seems that it has not a normative but descriptive character. In this meaning a principle means a description of the shape of the institution, therefore de facto a description of the content of legal norms (not necessarily norms applicable in a specified legal system-they can include merely presupposed norms). In this meaning a principle falls rather under the category of assertives. On the other hand, it is not about any way of shaping the legal institution, but about the way which is somehow significant from the point of view of a given branch of law or the entire legal system (often being an expression of adopting certain philosophical or political assumptions). It is indeed the dimension of "weight" $[29,82]$ of principles in this meaning that makes them pure descriptions, or rather descriptions associated at least with a suggestion or recommendation. In the framework of this paper it is difficult to analyse this notion more broadly, which is why to simplify things it shall be assumed that a pure description is being dealt with here.

Taking into account current assumptions one can tell that the nature of a principle (being a principle) is determined not so much by the semiotic (pragmatic) type of

\footnotetext{
1 Alexy distinguishes two different types of norms: principles and rules [1]. In his approach, they differ in structure. We will not assume such a distinction in this study.

2 The presence of these two meanings in the language of dogmatics was pointed out by Ziembiński et al. [83].
} 
an utterance, but the weight of its content. As is known, different speech acts (e.g. statement, request or wish) may have the same propositional content (what is stated; what is requested; what is wished; etc.). Assuming that the propositional content is a characteristic of a given state of affairs $\mathrm{P}$, one can say that for example a norm ordering the implementation of $\mathrm{P}$, a statement that $\mathrm{P}$ as well as a request that $\mathrm{P}$ be caused share the same propositional content P. Referring the above to the subject matter discussed here, one can tell that a norm of conduct (binding or only presupposed), a teleological directive, a (model) standard of shaping the institution or a constitutive rules may have the same propositional content, that is demonstrate the same state of affairs, yet in each of these utterances their semiotic (pragmatic) modus will be different. If additionally, this propositional content will have the dimension of weight then each of these utterances may be treated as a principle. If for instance the adversarial nature of proceedings will be the propositional content then an adequate principle as a norm applicable in a specific procedure will order the court under certain circumstances to withdraw from any initiative in terms of factual and legal findings and to limit itself in this regard only to parties' requests; in turn, a teleological principle-directive will demonstrate that e.g. such a way of regulation most effectively makes it possible for parties to pursue their subjective rights. A principle/model will characterize this way of organizing a trial as one of the possible ones (in contrast to the inquisitorial system). In turn, an adequate principle-rule of meaning may e.g. point out that only activities carried out in conditions of the adversarial system will be treated as valid.

In dogmatics, often when attempting to explain the notion of the principle of law a vague term "legal idea" is used, at the same time not pointing out what such an idea is. The notion of propositional content is a good exemplification of the said notion of an idea, that is what is common, to different meanings of the expression "principle of law".

Using the findings so far it can be said that what in legal literature is called "principles of criminal liability" or "principles constituting the system of criminal liability" are in essence certain sets or "packs" of interrelated norms, teleological directives, models of shaping the institution of criminal law as well as constitutive rules. Employing this finding in a further part of the study, we will try to analyse different principles of criminal liability and types of systems of criminal law, order them and extract essential related notions.

\section{Possible Ways of Understanding Principles of Criminal Liability}

TheChristian-canonical-Roman jurisprudence is a source of such a model of thinking of the law (in the pragmatic context-making the law, as well as non-pragmatic-expectations as to the creations of this process) in which a particular role is played by synthesizing and grouping contents of the law [52: 132]. Such an ordering role (one ordering the legal knowledge, values and abundance of axiological contents) is played by principles of law (understood as "legal ideals"). In criminal law these are principles of criminal liability. Basic principles are formulated as simple formulas that are easy to understand (even by a layperson) which are a reflection of 
conditions of bearing the liability. They include in particular conditions of applying criminal sanctions and in a clear (though simplified) manner specify the notion of a crime [11: 18-21]. They often are reflected in the text of criminal laws. Therefore, they are principlesnullumcrimen sine damno sociali magis quam minimo, nullumcrimen sine culpa, nullapoena sine lege, nullumcrimen sine legecertaetc. ${ }^{3}$

Certainly principles of criminal liability may be understood as rules or norms outlining orders or prohibitions and standing out among other norms with their weight, for legal culture, legal doctrine, etc. [e.g. 1: 294-304; 28: 14ff]. In such a classic approach they are norms defining basic rights and obligations in the applicable criminal law (lege lata level) [82: 179-188; 59: 79-93]. However, is it the only possible and cognitively interesting meaning of the word "principle" in jurisprudence?

Referring to the basic findings of point 2 one can say that in analogy to principles of law in genere, principles of criminal liability may be understood as particularly weighty norms. Principles of criminal liability may be certain standards (models) of shaping criminal law or may describe the model system of criminal liability and its particular elements. As such, principles are rooted not so much in the law, but in culture (legal culture). As part of it, they can take various forms, shapes and roles [see 29: 22ff].

Principles which are models of shaping criminal liability and criminal law may be used in the process of creating criminal law at the national and transnational level (they will be applied by the legislator, the legal doctrine-the science of the law). These models as such also outline certain ideals. When the law concerning criminal liability (both at the level of the constitution and criminal statutes) was being created after the political transformation in Poland, models of liberal-democratic law adopted from Western countries were a certain pursued ideal. As such, principles that are models may be a criterion for assessing the law and a source of de legeferendapostulates. Whereas in the socialist period (in Poland and in the so-called Eastern Bloc countries) legal models form Western countries were a lexlataassessment criterion for the opposition and groups protesting against the system, that is a criterion for assessment of applicable norms, sets of norms or the institution of criminal law. Such ideals do not need to derive from models implemented in an actually applicable law, but from certain models shaped by the science of law. A model of criminal liability compliant with the model of social defence or of a retributive model may be such an ideal. They can be a criterion for assessing the applicable system of criminal law [see: 77: 69ff.; 7: 145-163; 75: 155-230; 83: 81-118].

In the above two approaches principles of criminal liability apply to forecast or applicable law. Last but not least these principles may also be understood as certain directives concerning the construction, shape and content of the system of criminal law [see 58: 411-432]. In such an angle, the principles will outline a certain model of shaping the system of criminal law. In this context principles of criminal liability do not have to be norms of procedure in their strict sense. These rules do not have a homogenous character, though they somehow have a fundamental (basic) character. They refer to creating the law not only in the formal but also content-related aspect.

\footnotetext{
3 Each of these Latin formulas has an equivalent in a national language.
} 
They have predominance over other norms of the legal system. It can be said that they have the nature of meta-law, though they do not seem possible to be characterized as only norms. They are rather sets of norms, constitutive rules, teleological directives as well as objectives and values justifying them. Principles understood as such can be described by the name of "rules constructing the system of criminal liability" (such rules may construct conditions of criminal liability and affect the content of criminal laws in their general part).

\section{Types of Rules Constructing the System of Criminal Liability}

Referring to the conclusions of point 2 one can say that rules specifying (constructing) the system of criminal liability may be approached in three ways: as firm norms, technical directives and the so-called constitutive rules (rules of valid performance of conventional activities [80: 201-215]).

Therefore, these rules may be firm norms addressed to the legislator and ordering or prohibiting the creation of institutions or principles of liability in a certain way. Philosophical and legal assumptions and the way of understanding the law determine whether these norms are classified as autonomous (that is self-imposed by the legislator - as on the ground of classical legal positivism) or whether they have their source in legitimacy, morality or tradition (perspective of natural law). ${ }^{4}$ They will include norms ordering the adoption of such and such models and the creation of criminal law based on these models (i.e. models describing the way of shaping criminal liability). They will then bring an obligation to adopt certain legislative solutions [cf. 81: 181-200; 19: 31-38].

Certain traces of such obligations may be noticed in the law itself. For example, the constitution might provide for the principle of guilt and social danger of an act as a principle of criminal liability - then the source of the obligation to adopt certain legislative solutions is clear. Usually the content of the constitution is a result of a certain decision anchored in something of a social consensus type, and in this sense the legislator binds himself by the authority of certain structural rules by a certain way of regulating the public sphere, including criminal liability. These can be rules resulting from the value of the principle of the rule of law, a certain philosophical, legal or ideological tradition (after the October Revolution the communist governments adopted the no-fault principle-associating classic bourgeois crimes with social injustice, yet formulating the law punishing for dangerous acts from the point of view of revolutionary awareness etc.) [73: 359-374; 52: 249-291].

In the second approach rules of the structure of criminal liability will involve teleological directives. If one were to assume that the legislator wants to create effective law meeting certain requirements of correctness, fairness, instrumental effectiveness, he should be guided by such or other technical directives [see 18: 12]. Therefore, rules constructing the system of criminal liability should be treated as directives pointing to the way one should take up in order to create a set of principles of

\footnotetext{
${ }^{4}$ It is worth pointing out that it involves constructing a legal and natural notion of a crime.
} 
criminal liability corresponding to the assumptions (of the legislator, philosophers, politicians). The legislator may adopt such rules the way he drew on the achievements of the representatives of the mainstream of the Enlightenment humanitarian reform or referring to various standards or model criminal regulations created by the legal doctrine [cf. 9: 1269-1334; 24: 509-572].

In the last possible approach the rules of construction of criminal law, including criminal liability, may have a constitutive character specifying the validity of the complex conventional act of creating a new law-issuing normative acts (which may be a valid or invalid act, depending on its compliance with applicable rules for performing law-creating acts, e.g. passing resolutions). It is interesting in this context that one can imagine a vision of criminal law which due to the punitive and repressive nature of a criminal punishment requires meeting special conditions in order to make criminal statutes in a valid way-for example special majority, in order to pass a statute or to change principles of liability [44: 35, 122-156; 35: 74]. Apart from the rules of valid law creation there would be additional rules concerning the creation of criminal law-valid making of criminal statutes. These rules may be important for criminal law and criminal liability, to quote rules such as lex retro non agit, lex posteriori derogatlegi priori etc. [cf. 70: 109-150; 68: 1175-1188; 25: $1-38]$.

We believe that from the point of view of principles of criminal liability (principles of criminal law) one needs to investigate in particular the approach to the discussed rules as norms strictly binding the legislator to adopt certain resolutions in terms of creating criminal law. These would be in principle orders and prohibitions coming from the state itself (i.e. The legislator, the sovereign-thus they would be autonomous since they are addressed to the creator itself, just like rules specifying the content of a contract in private law or international public law), which prima facie could be amended, repealed, revoked or supplemented at any time [62: 12-19; 69: 319-356]. They would also order the adoption of such teleological directives not others, that is they would order the application of strictly defined measures in order to achieve the objectives adopted by the legislator. In this sense they would outline directions of law politics, while the main objective would be to combat broadly understood crime. To talk more specifically, norms ordering the application of such or other technical directives would have to be formulated on the basis of specified knowledge, in particular knowledge on combating crime (criminological, sociological, psychological, etc.). The criminal policy must then assume that the legislator may be personified and attributed certain rationality. Rationality of the legislator would encompass both sociotechnical knowledge about reasons for crime and combating it attributed to him, as well as assessments and values he is guided by. Therefore, it is a certain idealization (counter-factual) model of a rational legislator. Such rationality may be attributed to a legislator understood as an entity with law-making competence, who is a certain legal convention but not necessarily to a sociological (actual) legislator, that is a person or group of people actually creating law, since he is often guided by a political interest or simple emotions (having little to do with rationality, also instrumental rationality). Creating a model of a rational criminal legislator (close to for example J. Bentham) has a practical sense because first it can 
serve the assessment of legislative activities, and second, as a means of streamlining the practice of application of criminal law [8; 53: 137-147; 41; 69: 39-62].

Such an ideal rational legislator may be understood as a model for real legislators and political decision-makers as well as bodies applying criminal law who due to their social role should strive to achieve perfection in their field understood in any way, more or less like for Christians a person considered saint is a model (anyway, one cannot exclude the inclusion of such an obligation, perfection, in a catalogue of moral-political obligations, following the ethics of the Greek polis).

\section{Basic Principles of Criminal Liability}

Establishing rules of criminal liability understood as rules constructing the system of criminal liability depends on a number of conventions, also those more associated with jurisprudence, that is those relating to the sources of law or rules of interpretation. A certain act is a crime and a response to it a punishment only in a given social set-up, the same as criminal liability is constructed on the ground of a given social set-up [56: 5].

Legal reflections must always take into account the statute and other legally significant materials, but they cannot be isolated from a broader cultural context. A lawyer must attribute a greater role to legal texts and practices than a philosopher or ethic would do. However, only superficially is the horizon of legal argumentation limited by the legal text, even in criminal law. Not only a philosopher can for instance discuss a problem whether the constitution should be respected. The political situation in Poland and other countries shaken by undermining the rule of law (like Hungary) teaches that lawyers can also argue for the thesis that the Constitutional Tribunal in not anchored in the constitution or, on the other hand, for the thesis that the constitution is not binding.

Then, what outlines the scope of criminalization or criminal liability? It seems that in the case of criminal law a basic principle that has a cultural rather than a legal source is the principle utlima ratio. A criminal sanction is the furthest response to an unlawful act and thus criminal law plays the a somehow subsidiary role towards other ways of solving social problems or combating undesirable phenomena from a certain essential point of view [55: 250]. Taking into consideration semiotically distinguished modi of principles of liability it may be said that the principle ultima ratio has basic significance, understood as a norm ordering the legislator to apply a criminal sanction only when other measures prove ineffective. However, it seems that this principle may be also understood as a teleological directive. It can be attributed at least two interpretations" "sociotechnical" and "axiological". In accordance to the first one, a criminal sanction may be an effective response to undesirable phenomena only when other measures fail. According to the second one, in order to create a legitimate and fair law one needs to apply a criminal sanction only as a last resort. As can be seen, they are based on slightly different assumptions. The first interpretation assumes that in an adequately long-term perspective measures other than a criminal sanction are more effective. In turn, the second one is based on the assessment what criminal law is good and legitimate. These interpretations are 
independent of each other-one can accept one of them at the same time rejecting the second one.

Further principles result from the idea of the rule of law. It has far-reaching consequences in the field of criminal law. In the systems of given law they will include prohibition of applying analogy, prohibition of retroaction (lex praevia), the principle of clear and precise defining crimes (lex certa), but also the principle of strict interpretation of criminal law (lexstricta), as well as the rule of persecuting and punishing only those acts that have been specified in the criminal act at the moment of committing them and only with punishments then provided for under criminal law. It can be assumed that these principles specify certain obligations. These are norms specifying obligations of lawyers (e.g. advocates or judges), regarding a broad spectrum of their activity (e.g. way of interpreting and arguing) as well as the legislator [20:89-103]. As far as the prohibition of retroaction and the principle of certainty of a crime, they can be also understood as specific constitutive rules-rules of valid making of criminal statutes. Their violation causes far-reaching defectiveness of law-making acts. In principle, rules concerning the interpretation and application of criminal law may also be understood as teleological directives outlining how to correctly interpret and apply the law.

A. Ashworth, in reference to the common law system, identifies the following principles: the principle of individual autonomy, the principle of welfare, the harm principle and public wrongs, the minimalist approach, morally wrong behaviour, remote harms [4:68]. They fully inscribe themselves in the scheme of rules constructing the system of criminal liability. They are determinants of the policy of law, ideals and models of shaping the criminal law. They outline the scope and boundaries both in reference to creating criminal law as well as criminal liability. They permeate criminal law universally and they cannot be brought down to the role of regular code norms - liability requirements. The legislator cannot create criminal law in a completely free way. He is obliged to respect the rules constructing a given legal system. Another issue concerns the fact in what scope the legislator may influence that rules. As a famous saying goes: parliament can do everything but make a man a woman-it is rather a boastful thing since in fact it is bound by a number of extralegal and quasi-legal norms and assessments.

\section{Types of Systems of Criminal Liability}

The conceptual grid applied for the needs of this reflection allows a formulation of various typologies of criminal law systems. They refer to different aspects of criminal liability. The most important ones can include two aspects, that is procedural (formal) and material.

Under the procedural plane, one can distinguish rules constructing the process of holding someone liable. They affect the shaping of criminal law as such. When making a historical generalization, one can distinguish two basic types, that is contradictory and inquisitional, as well as a mixed type (combining those two elements). These types do not have to be discussed but they are universally known. 
Nevertheless, it is important that the type is selected at the outset of making law [cf. 51: 204-220; 51].

In the material aspect it is worth noting the transformation of criminal liability in the direction of its subjectivitization. The type of objective liability features formal liability for the mere committing of the act or occurrence of a fact considered a crime, at most based on the cause-effect relationship. Such liability may be borne by people, animals or even forces of nature. Rules constructing this type of criminal liability adopt the rule of criminal response to undesired facts-events or acts. The type of subjective liability admits the principle of guilt (nullumcrimen sine culpae), and at least of taking into account bad intentions (dolusmalus) as a condition for penalizing [30; 32: 24-40].

These examples are essential in the respect that contemporarily, at the level of the principle of the rule of law, classification of criminal law under the second type is predetermined. However, it is worth noting that the rules constructing the system order the application of criminal liability only on the basis of guilt in order to saturate to an adequate degree the criminal response with a subjective element (hence admissibility of strict liability in certain systems). These are issues related to a specified legal culture. In turn, even though the type referring to the idea la socjaledefense minimizes the role of guilt understood dogmatically, due to its focus on a person (offender) gains a character of a specific case of subjectivism [see: $2 ; 3: 13$; 83: 81-118; 61: 187-205; 28: 97].

A question arises whether a criminal statute that addresses criminal response that is not based on guilt is indeed criminal liability by the power of constructing rules or rather quasi-criminal or administrative. In other words, can the principle of guilt be treated not only as a norm of procedure addressed to the legislator, but also as a constitutive rule constituting the activity of making criminal laws. In this sense, settling the semiotic status of certain rules constructing the system of criminal law is key for the practice of creating law. In the Polish legal system liability of collective entities may be such an example - the Polish Constitutional Tribunal has spoken on this subject recognizing liability of these entities as repressive but not criminal, indeed due to the absence of the premise of guilt. However, it is disputable whether the system allows such indirect types.

Such a question raises a further problem. The rules constructing the system of criminal liability may be perceived as such that concern performing conventional activities, in this case creating law (criminal law). A conventional act of creating law may be valid if performed according to relevant rules. Does the compliance of a created criminal law with recognized models of criminal liability fall under the content of these rules? Whereas it is not only about a formal criterion of norm applicability, but about the possibility of including these norms in criminal (and not, e.g. repressive) law.

Alice Ristroph distinctly emphasizes the strict relationship between justification being penalized by the state and this state's meeting basic, that is expected in a given social-historical-cultural set-up, standards allowing political legitimization of a given state. The notion of political legitimacy to penalize can be illustrated by extreme examples, drawing on most recent history. Were any penalties imposed by the Nazis or the Stalinist regime justified [43; 62: 76-92; 63: 77-80]? 
In the contemporary literature on criminal liability, including literature concerning justification of penalizing and normative guidelines regarding directions of criminal policy (encompassing the creation, interpretation and application of the law) a contractarianist liberal-democratic model dominates, based on the ideas of participatory democracy [61: 10-17, 55-64]. It is of course a certain model which is an idealization of reality, but despite of it it is a response to the reality of current societies with an Enlightenment tradition in which it is rooted [cf. 14: 249-271; 12: 778-789; 10: 66-67]. It is also a certain reference point for the way of shaping criminal law as a certain model made up of a number of principles directed at the legislator, who should take them into account creating criminal regulations. As pointed out, they can be principles which in essence are constitutive rules constituting the act of creating criminal law. The legislator will take them into account as much as he aspires or wants to remain in a certain circle of the legal culture. Naturally, there is no single concept depicting the spirit or essence of this culture. However, it is outlined in an essential way by modern understanding of the principle of the rule of law, democracy, social and ethical pluralism and other values rooted in ethical intuitions [cf. 23; 26]. ${ }^{5}$ Let us call such a model liberal (which will be discussed later) [16; 39: 159-182].

Of course, from the point of view of legal and natural concepts a grossly unfair law is not applicable. As a result, acts considered crimes by this law are not crimes in the proper sense of the word "crime" (as a prohibited act under the pain of punishment by the law applicable at the time the act was committed). Consequently, the state's response to this act may be treated as terror or e.g. an isolation and elimination measure, but not criminal punishment.

The postulate (formulated in the philosophy of criminal law) to apply qualified majority in creating criminal statutes may be one of the interesting directions of application of principles understood as constitutive rules defining the manner of valid creation of criminal law. A solution existing in a lot of legal systems involving placing criminal law among the statutory matter may be perceived as a certain minimum [cf. 35]. In the end it is difficult to accept that criminal regulations should be the subject matter of implementing acts (or regulations essential for criminal liability-such as specifying crimes). Such a postulate encourages one to ask the most significant question. In a legal system where in order establish criminal law (e.g. by the power of constitution or rules of the parliament) qualified majority at voting is required, would an infringement of this requirement result in the adopted act not being treated as criminal? If the answer to this question is affirmative it means that in order to recognize the making of a legal act as an act of creating criminal law it is necessary to meet content requirements on the one hand and certain formal requirements on the other. Rules for creating criminal law may cover the specificity of the crime and the punishment. If, like in the circle of Eastern European systems of law, criminal liability is analytically related to the act and guilt, then liability without an act and guilt (e.g. collective entities), ex definitione will not be criminal liability (as

\footnotetext{
5 It is about intuitions of lawyers, judges, advocates or representatives of the science of the law, values expressed in assessments, manner and direction of interpretation of law, legal reasoning, etc.
} 
confirmed by the CT). If the legislator infringes rules of creating criminal law, for example introduces criminal liability by means of an implementing act, then it will simply not be criminal liability.

Wrong orientation of the political will may cause that a decision will be invalid, whereas incompliance with a culturally accepted model of shaping criminal law can make the act of creating law only seemingly involve issuing a criminal statute (a quasi-criminal statute, superficially criminal) [44: 35, 122-156].

The assessment of justification of decisions refers not only to the procedure of taking it, but also the entity taking the given decision. ${ }^{6}$ Democratic legitimacy is more than a procedure. The validly of a decision may be challenged if it is grossly unfair or by way of reductioad absurdum (self-annihilation or rejecting laws of physics cannot be democratically requested or voted for) [3: 442-457]. An answer to the question about the freedom of democratic decisions that elementary rationality and moral intuition rooted in societies that have experienced WWII order to give is negative. These experiences order a particularly detailed examination of decisions citing the good of the people, majority or nation, etc., even if they look seemingly harmless. It is a question of assessment which must take into consideration a cultural and social background, while the criteria for this assessment are not entirely clear [cf. 45; 48].

The use of criminal law as a hard political and ideological instrument involves primarily an assessment of the point of view of the principle of the rule of law [67: 1175-1188]. It seems that in the event of social and ethical defectiveness, the assessment of the activity of the legislator in the area of criminal law should be done on the basis of criteria analogical to criteria for the assessment of the activity of a judge of a criminal court [44:10-17, 55-64]. It seems, that there are two basic determinants of obligations of the legislator in criminal cases. Firstly, due to the rules constructing the system of criminal law in democratic and liberal conditions, the legislator is obliged to pursue ethical justification of penalization. Secondly, the legislator should display independence and impartiality, modelled after roles and obligations of a judge adjudicating in criminal cases [50: 204-235]. Somehow, putting the role of the court and the legislator next to each other should not be surprising. The sphere of creating and interpreting the law implicite overlap. If courts interpreting law in criminal cases are expected to show justice, fairness, impartiality and rational justification of decisions, then all the more so (or analogically) one can expect the legislator to be impartial [57: 75-105; 31: 62-72]. It has a different dimension, but it can be observed as well as assessed post factum-there are legislative procedures outlining the degree and scope of civic participation. However, complying with them is a certain minimum [cf. 13: 46ff.].

What are the consequences of violating the above directives? It seems that on a liberal-type ground a duly justified assessment that the legislator infringed obligations in terms of creating criminal law and the rules talking about how to issue an

\footnotetext{
${ }^{6}$ In democracy it will be people (demos), that is community members. Nevertheless, an adequate mode and subject (majority) are too little for a political decision to be deemed justified [see 38; 40: 39-62].
} 
act of criminal (not quasi-criminal or repressive) law in a valid way determines that a given normative act does not fall under criminal law. Then courts should recognize a given act as unconstitutional (if such directives are reflected in the constitution), or such an act should be treated as non-criminal with all related consequences, which includes civil disobedience towards the law (and it brings to mind Radbruch's differentiation between Rechts and Gesetz ${ }^{7}$ ).

A liberal type of criminal law was talked out above. It seems that regulation of the conditions for and subject of liability allows one today to include, apart from the liberal type, also other types of shaping liability in the law [see 51: 282-284; 46]; 42: 36ff.; 5: 1-31; 54: 377-392; 65: 43-50]. However, it needs to be added that the typology presented here is certainly not exhaustive [59: 79-93]. It is a certain subjective review done by the authors of this text referring here to certain universally known historical generalizations [60: 187-205; 64].

The communitarian type has a utilitarian (consequential) justification, while liability is included in mechanisms of prevention and resocialization [see: $21 ; 47$ : 49-53; 76: 7-37; 22: 3-18]. The conditions of responsibility are governed by the principle of social harm (social threat) of a behaviour (act) as a fundamental prerequisite of liability and moreover also the principle of guilt, form which exceptions are provided for [12: 1-28]. Therefore, the scope and subject of liability is outlined by harm as well as a threat to public morality and the idea of paternal protection of the good of the citizens [6:174-188]. It is admissible to hold the innocent liable and isolate people in a medical treatment (or other) mode and results of holding liable are not always proportional to the weight of the subject of liability [cf. 36: 829-839]. This type of criminal law refers philosophically to communitarian ideals. It is worth adding that rules constructing the system of criminal liability understood as teleological directives of a sociotechnical character in some sense gain special weight in such a type [33: 245-276]. They need to point out what shape of liability provides an effective measure of carrying out the good of the community [37: 27-52; 4 : 407-413].

Moreover, also an anti-democratic type can be distinguished. In this case criminal law is a tool of implementing a specified, associated with a specific moral doctrine) morality and vision of society. Specifying crimes is done in reference to ideology, excluding a discursive way of defining their content by interested citizens. Freedom, as a value, has a distant place in relation to collective goods (such as for example the interest of the nation). Punishment is supposed to be payback and serve apparent resocialization (or elimination-such as correctional camps in the Korean Democratic Republic) but directed especially at certain groups of offenders. Instrumentalisation of interests of victims of crimes is another element here [17: 1-15). An example here could be anti-refugee slogans (proclaiming their contribution to material increase of crime) and using victims of common offences for anti-immigration policy. Criminal law, punishing certain behaviours, outlines from the negative side models of practices, attitudes or mentalities desired by the authorities, serving not only the protection of morality but interests of the party or state authority. In a

\footnotetext{
${ }^{7}$ It is naturally not true that Gesetz ist Gesetz, as emphasized by contemporary philosophy of law [see 74].
} 
radical or totalitarian form, premises of liability are based entirely on a differently understood threat to society and state. Communist law in the initial stage of existence of the Soviet state or the Nazi law (that is German law from the period of the Third Reich or the Stalinist law in Poland of the mid-20 ${ }^{\text {th }}$ century) are examples of implementation of this type of principles of liability [see 42: 117-147; 71]. This type is characterized not only by liability on special conditions expressed in appointing special adjudicating institutions, usually proceeding on the basis of very simplified rules of procedure limiting evidentiary proceedings to the minimum (typically, there is no element of response to an allegation, but there is a punishment associated with either an undesirable act or with an undesirable state-for example class, racial or national affiliation) [72: 359-374; 34: 829-839]. Also in this case rules constructing the system of criminal liability understood as teleological directives with a sociotechnical character in some sense take on a special dimension. This is because they must point out what shaping of liability constitutes an effective measure of implementation of the good of the party, specified group or the nation [see: cf. 71: 35ff].

It is worth adding here that from the perspective of the liberal type, stating that criminal law in a given state in terms of significant features is getting closer to the anti-democratic model may predetermine recognition that a given normative act (or system of criminal law per se) is not in fact criminal law but a different (in any caserepressive) kind of law [cf. 49].

\section{Conclusion}

It seems that in theoretical reflections on criminal law it is worth referring to models that may be a starting point when constructing specific legislative solutions [cf. 27: 293-309; 46: 522-534]. Such models might be helpful also when formulating pan-national, for example European, criminal law. In this context a key role is played by the notion of principles of criminal liability. From the semiotic point of view they can occur in three forms: special-kind norms, teleological directives, rules which constitute valid performance of conventional activities (making criminal law). Moreover, in an extra-directival sense these principles may be understood as models-descriptions of shaping the system of criminal law (or criminal liability as the core of criminal law). From a theoretical and practical point of view principles addressed to the legislator are extremely weighty-they can be called rules constructing the system of criminal liability. The semiotic status and content of these rules makes it possible to formulate a number of detailed notions, such as e.g. the problem of minimum content requirements which allow one to recognize a given act of making law as an act of making criminal law (in the liberal mode it will involve in particular basing liability on the principle of guilt). The content of rules accepted in a given legal system allows one to distinguish certain types of criminal law: liberal, communitarian and anti-democratic.

The application of basic notions of the semiotics of directives to the subjectmatter of criminal liability presented in the paper allowed obtaining results which would have been difficult to obtain without adopting "a semiotic point of view", such as indicating possible ways of understanding principles of criminal liability and 
constructing the notion of rules of construction of the system of criminal liability. As a result of the analysis it was possible to carry out a practically useful typology of systems of criminal liability [cf. 15; 36: 53-74]. It is worth adding that special importance was given in this paper to values attitude to which became even the criterion for identifying types of systems of criminal liability. Similarly, the attitude to values is, on the basis of the conducted analyses, one of the key factors allowing identification of rules of construction of a system of law as a special type of principles of law. One needs to note that principles of law as rules of constructing the system of law have not been subject of sufficient focus to date. The principles of law appeared in the theoretical and legal thought primarily in reference to application of the law. The paper points to the usefulness of this notion also in the analysis or theory oflaw-making. The research findings may be easily extrapolated on branches of law other than the criminal law.

Complexity and multitude of aspects of theoretical reflections on criminal law is vast. This is why, to conclude, it is appropriate to express a belief that systemizing work on criminal law and forecasting its changes, also in the sphere of transnational law, seems an inherent value worth pursuing. In the author's intention this study is to contribute to its implementation.

Open Access This article is licensed under a Creative Commons Attribution 4.0 International License, which permits use, sharing, adaptation, distribution and reproduction in any medium or format, as long as you give appropriate credit to the original author(s) and the source, provide a link to the Creative Commons licence, and indicate if changes were made. The images or other third party material in this article are included in the article's Creative Commons licence, unless indicated otherwise in a credit line to the material. If material is not included in the article's Creative Commons licence and your intended use is not permitted by statutory regulation or exceeds the permitted use, you will need to obtain permission directly from the copyright holder. To view a copy of this licence, visit http://creativecommons.org/licen ses/by/4.0/.

\section{References}

1. Alexy, Robert. 2000. On the Structure of Legal Principles. Ratio Juris 13(3): 294-304.

2. Ancel, Marc. 1965. Social defence. A modern approach to criminal problems. London: Routledge and Paul Kegan.

3. Sala, Aguirre, and Jorge Francisco. 2015. The Model of Participatory Democracy Powered by New Media. You are not Citizen to Participate; You Participate to Become a Citizen. ArchivfürRechtsund Sozialphilosphie 3: 442-457.

4. Andrew, Ashworth, and Jeremy Horder. 2006. Principles of Criminal Law. Oxford: Oxford University Press.

5. Anderson, Scott A. 2010. The Enforcement Approach to Coercion. Journal of Ethics and Social Philosophy 5(1): 1-31.

6. Bayles, Michael. 1974. Criminal Paternalism. In The Limits of Law, ed. J.R. Roland Pennock and J.W. Chapman, 174-188. New York: Lieber-Atherton.

7. Bennett, Christopher. 2002. The Varieties of Retributive Experience. Philosophical Quarterly 52(207): 145-163.

8. Bentham, Jeremy. 1817. A Table of the Springs of Action. London: R. Hunter.

9. Bilionis, Louis D. 1998. Process, The Constitution, and Substantive Criminal Law. Michigan Law Review 96(5): 1269-1334.

10. Bobbio, Norberto. 1993. Thomas Hobbes and the Natural Law Tradition. Chicago: The University of Chicago Press. 
11. Bohlander, Michael. 2009. Principles of German Criminal Law. Oxford, Portland, Oregon: Hart Publishing.

12. Branstetter, John. 2017. The Leviathan's Conscience: Hobbesian Human Nature and Moral Judgment. Political Research Quarterly 70(4): 778-789.

13. Cass, Ronald A. 2011. The Rule of Law in America. Baltimore: JHU Press.

14. Carvalho, Hamilton. 2017. Liberty and Insecurity in the Criminal Law: Lessons from Thomas Hobbes. Criminal Law and Philosophy X 11: 249-271.

15. Chiao, Vincent. 2016. Two Conceptions of the Criminal Law. In The New Philosophy of Criminal Law, ed. Chad Flanders and Zachary Hoskins, 20-36. Lanham: Rowman and Littlefield.

16. Christie, Nils. 1986. Crime Control as Drama. Journal of Law and Society 13(1): 1-18.

17. Christie, Nils. 1977. Conflicts as Property. British Journal of Criminology 17(1): 1-15.

18. Cragg, Wesley. 2016. The Practice of Punishment: Towards a Theory of Restorative Justice. London, New York: Routledge.

19. Czepita, Stanisław. 1994. Reguły konstrukcji systemu prawnego a prawotwórstwo. [Rules of Construction of a Legal System and the Law-Making Process]. RuchPrawniczy, EkonomicznyiSocjologiczny LVI 4: 31-38.

20. de Greiff, P. 2002. Deliberative Democracy and Punishment. Buffalo Criminal Law Review 5(2): 373-403.

21. Erik, Claes, and Michal Krolikowski. 2010. The Limits of Legality in the Criminal Law. In Facing the Limits of the Law, ed. Erik ClaesWouterDevroe Bert Keirsbilck, 89-103. Dordrecht: Springer.

22. Dolinko, David. 1991. Some Thoughts about Retributivism. Ethics 101(3): 537-559.

23. Dripps, D.A. 1998. The Liberal Critique of the Harm Principle. Criminal Justice Ethics 17: 3-18.

24. Dubber, Markus Dirk. 2004. Toward a Constitutional Law of Crime and Punishment. Hastings Law Journal 55(3): 509-572.

25. Dubber, Markus Dirk. 2005. The Promise of German Criminal Law: A Science of Crime and Punishment. German Law Journal 1049(6): 1-38.

26. Duff, Robin Antony. 2007. Answering for Answering for Crime: Responsibility and Responsibility in the Criminal Law. Oxford, Portland: Hart Publishing.

27. Duff, Antony. 2010. Criminal Law for Citizens. Theoretical Criminology 14: 293-309.

28. Dworkin, Robert. 1969. The Model of Rules. In Law, Reason, and Justice, ed. Graham Hughes, 14-29. New-York, London: University of London Press.

29. Dworkin, Robert. 1980. Taking Right Seriously. Harvard, Cambridge: Harvard University Press.

30. Feinberg, Joel. 1970. The Expressive Function of Punishment. Princeton: Princeton University Press.

31. Feteris, Eveline T. 1999. Fundamentals of Legal Argumentation. A Survey of Theories on the Justification of Judicial Decisions. Dordrecht: Springer.

32. Fischer, John Martin. 1982. Responsibility and Control. Journal of Philosophy 79: 24-40.

33. Fleurbaey, M. 2008. Fairness, Responsibility, and Welfare. Oxford: Oxford University Press.

34. Frankfurt, Harry. 1969. Alternate Possibilities and Moral Responsibility. Journal of Philosophy 66: 829-839.

35. Fuller, Lon. 1969. The Morality of Law, Revised ed. New Haven: Yale University Press.

36. Gainer, Ronald. 1998. Federal Criminal Code Reform: Past and Future. Buffalo Criminal Law Review 45(2): 53-74.

37. Garland, David. 2001. The Culture of Control: Crime and Social Order in Contemporary Society. Chicago: The University of Chicago Press.

38. Habermas, Jurgen. 1987. The Theory of Communicative Action, System and Lifeworld: A Critique of Functionalist Reason. Boston, MA: Beacon Press.

39. Hampton, Jean. 1994. Liberalism, Retribution and Criminality. In Harm's Way: Essays in Honor of Joel Feinberg, ed. Jules L. Coleman and Alan Buchanan, 159-182. New York: Cambridge University Press.

40. Harsanyi, John. 1982. Morality and the Theory of Rational Behaviour. In Utilitarianism and Beyond, ed. Amartya K. Sen and Bernard Williams, 39-62. Cambridge: Cambridge University Press.

41. Hiroven, Ari. 2010. Total Evil: The Law Under Totalitarianism. In Law and Evil. Philosophy, Politics, Psychoanalysis, ed. Ari Hirvonen and Janne Porttikivi, 117-147. New York: Routledge.

42. Honderich, Ted. 2005. Punishment The Supposed Justifications Revisited. London: Pluto Press.

43. Husak, Douglas. 2008. Overcriminalization. The Limits of the Criminal Law. New York: Oxford University Press.

44. Jareborg, Nils. 2004. Criminalization as Last Resort (Ultima Ratio). Ohio State Journal of Criminal Law 2: 522-534. 
45. Johnson, O.A. 1969. Rightness and Goodness. A Study in Contemporary Ethical Theory. Hague: The MartinusNijhoff.

46. Kaufman, Arnold. 1960. The Reform Theory of Punishment. Ethics 71(1): 49-53.

47. Kymlicka, Will. 1989. Liberalian. Community and Culture. Oxford: Oxford University Press.

48. Kymlicka, Will. 2001. Contemporary Political Philosophy: An Introduction. Oxford: Oxford University Press.

49. Los, Maria W. 1988. Communist Ideology, Law and Crime. A Comparative View of the USSR and Poland. London: Palgrave Macmillan.

50. Lucas, John Randolph. 2004. Responsibility. Oxford: Oxford University Press.

51. Merryman, John Henry. 1969. The Civil Law Tradition. An Introduction to the Legal Systems of Western Europe and Latin America. Stanford: Stanford University Press.

52. Nowak, Leszek. 1987. A Concept of Rational Legislator. In Polish Contributions to the Theory and Philosophy of Law. Series: Poznań Studies in the Philosophy of the Sciences and the Humanities, ed. Zygmunt Ziembiński, 137-147. Amsterdam: Brill Rodopi.

53. Nozick, Robert. 1981. Philosophical Explanations. Cambridge, MA: Harvard University Press.

54. Packer, Herbert L. 1968. The Limits of the Criminal Sanction. Stanford: Stanford University Press.

55. Parnell, Philip C., and Stephanie C. Kane (eds.). 2003. Crime's power. Anthropologists and the ethnography of crime, 5. New York and Basingstoke: Palgrave.

56. Peczenik, Aleksander. 2005. Scientia Juris: Legal Doctrine as Knowledge of Law and as a Source of Law. Dordrecht: Springer.

57. Peno, Michał. 2019. Philosophy of Punishment: Normative Models and Construction Principles of Legal Systems. ZbornikPravnogfakulteta u Zagrebu 69(3): 411-432.

58. Peno, Michał. 2019. The Character of the Principles of Criminal Law and Criminal Responsibility: Between the Philosophy of Law and Semiotic. Liverpool Law Review 40(2): 79-93.

59. Pereboom, Derk. 2003. Living Without Free Will. New York: Cambridge University Press.

60. Primoratz, Igor. 1989. Punishment as Language. Philosophy 64(248): 187-205.

61. Ripstein, Arthur. 1999. Equality, Responsibility and the Law. New York: Cambridge University Press.

62. Ristroph, Alice. 2016. Two Conditions of Legitimate Punishment. In The New Philosophy of Criminal Law, ed. Chad Flanders and Zachary Hoskins, 76-92. New York: Rowman and Littlefield.

63. Ross, Alf. 1968. Directives and Norms. London: Routledge \& Kegan Paul Ltd.

64. Ryberg, Jasper. 2004. The Ethics of Proportionate Punishment. A Critical Investigation. Dordrecht: Kluwer Academic Publishers.

65. Searle, John R. 1975. A taxonomy of illocutionary acts. Language, Mind and Knowledge, Minnesota Studies in the Philosophy of Science 7: 344-369.

66. Sadurski, Wojciech. 1988. Theory of Punishment, Social Justice, and Liberal Neutrality. Law and Philosophy 7(3): 351-373.

67. Scalia, Antonin. 1989. The Rule of Law as a Law of Rules. University of Chicago Law Review 56(4): 1175-1188.

68. Selznick, Philipp. 1994. Moral Commonwealth: Social Theory and the Promise of Community. Berkeley: University of California Press.

69. Shapiro, Ian. 2003. Moral Foundations of Politics. New Haven: Yale University Press.

70. Skinner, Stephen. 2015. Fascism and Criminal Law: History, Theory, Continuity. Oxford, Portland, Oregon: Hart Publishing.

71. Snyder, Timothy. 2016. Black Earth: The Holocaust as History and Warning. New York: Tim Duggan Books.

72. Starosolsky, George V. 1950. Principles of Soviet Criminal Law. North Carolina Law Review 28(4): 359-374.

73. Strawson, Peter F. 1962. Freedom and Resentment. Proceedings of the British Academy 48: 187-211.

74. Tebbit, Mark. 2005. Philosophy of Law. London, New York: Routledge.

75. Ten, Chin Liew. 1989. Crime, Guilt, and Punishment. Oxford: Clarendon Press.

76. Tunick, Mark. 1992. Punishment. Theory and Practice. Los Angeles, Oxford: University of California Press.

77. Vilhauer, Benjamin. 2013. Persons, Punishment, and Free Will Skepticism. Philosophical Studies 162(2): 143-163.

78. von Wright, and Georg Henrik. 1963. Norm and Action. A Logical Enquiry. London: Routledge \& Kegan Paul.

79. von Wright, and Georg Henrik. 1985. Is and Ought. In Man, Law, and Modern Forms of Life, ed. E. Bulygin, J.-L. Gardies, and I. Niiniluoto, 6-17. Dordrecht: Reidel. 
80. Woleński, Jan (ed.). 1999. Some Problems of the Theory of Norms. In Kazimierz Opatek Selected Papers in Legal Philosophy, 201-215. Dordrecht: Springer.

81. Wronkowska, Sławomira, Maciej Zieliński, and Zygmunt Ziembiński. 1987. The Methodological Problems Concerning The Principles of Law. In Polish Contributions to the Theory and Philosophy of Law. Series: Poznań Studies in Philosophy of the Sciences and the Humanities, ed. Zygmunt Ziembiński, 179-188. Amsterdam: Brill Rodopi.

82. Wróblewski, Jerzy. 1990. Principles, Values, and Rules in Legal Decision-Making and the Dimensions of Legal Rationality. Ratio Juris 3(1): 100-117.

83. Zaibert, Leo. 2006. Punishment and Revenge. Law and Philosophy 25(1): 81-118.

Publisher's Note Springer Nature remains neutral with regard to jurisdictional claims in published maps and institutional affiliations. 